\title{
Assessment of Farmers (Women)' Access to Agricultural Extension, Inputs and Credit Facility in Sabon-Gari Local Government Area of Kaduna State
}

\author{
${ }^{* 1}$ J.O. Owolabi, ${ }^{2}$ B.Z. Abubakar and ${ }^{3}$ M.Y. Amodu \\ ${ }^{1}$ Dept. of Agricultural Engineering, Institute for Agricultural Research, Ahmadu Bello University, Zaria \\ ${ }^{2}$ Dept. of Agricultural Economics and Extension, Usmanu Danfodiyo University, Sokoto \\ ${ }^{3}$ Dept. of Agricultural Economics and Rural Sociology, Ahmadu Bello University, Zaria \\ [*Corresponding author E-mail: jolaowo@yahoo.co.uk]
}

\begin{abstract}
This study examines the accessibility of women to three main production inputs namely: Farm inputs (fertilizers, modern technology, improved seed etc), Credit facility and Contact with extension agents. Structured interview schedule, personal observation and analysis of records were used to collect information for the study. The findings revealed that women in the study area were engaged in farming activities such as crop production and rearing of livestock. Traditional technology is still the practice among women farmers. Majority of the women sampled were small-scale farmers with low level of income and education. Women interviewed complained of lack of access to farm inputs, credit facilities and contact with extension workers, the situation which has constrained them from investing in agricultural production. The study recommended that women farmers should be given incentives, particularly in the area of production inputs (credit facilities, fertilizer, and improved seeds among others) and educational opportunities.

Key words: Assessment, Farmers, Access, Agricultural Extension, Credit Facility.
\end{abstract}

\section{INTRODUCTION}

The contribution of women in agricultural development is an established fact. Women are equal partners to men in all chains or aspects of agricultural production. Women are responsible for at least $70 \%$ of food staple production in Africa (World Bank, 1989). They are also important in other agricultural activities, including food processing, marketing, cash crop production, and livestock. Womenôs involvement is significant not only in terms of their labour input, but also in terms of decision-making authority. Jiriko (1999) also stated that the agricultural production and the living standards of a nation could not be improved unless women are actively involved. $\mathrm{He}$ classified the agricultural participation of Nigerian women farmers into four broad activities namely:

\section{i. Cultivation \\ ii. Harvesting \\ iii. Distribution and \\ iv. Alimentation, which entails processing of farm produce for home use}

Adisa and Okunade (2005) listed some constraints which limit women's access to extension services. First, in many places, cultural restrictions prevent male extension officers from meeting with women farmers. Secondly domestic responsibilities sometimes limit women's mobility and making it harder for them to attend courses away from home. Thirdly, the third world women are less likely than men to speak the national official language and extension services are often not offered in the local language. Fourthly, there are not enough female extension agents (Saito et al., 1992).

Furthermore, Nigeria women despite their participation in agricultural development, it has been observed that they are faced with many problems. Women's role in agricultural development has been traditionally under-rated owing to the argument that they are not major contributors to development process but rather as beneficiaries of development (Adisa and Okunade, 2005). This study was aimed at investigating the extent to which women in the study area has access to the services of farm inputs, credit facilities, and extension agents.

Problem statement: The functions of women are many and well known but very little ñfactsò have been documented about their economic activities. 
From literature, it was clear that women's contribution to agricultural development in the study area was low (Owolabi, 2001). It has also been observed that the cause of this inadequate contribution was due to low farm inputs that are made available to them (Dôsilver and Raza, 1980). Women are under privileged when it comes to having access to the tools of development and the means of raising the quality of life such as access to farm inputs, credit facility and extension services. They are hardly reached by extension agents (Atala, 1988).

Despite undeniable evidences of womenôs positive roles in the agricultural sector and growing awareness of the need to reach out to women farmers, agricultural extension services are generally geared toward male farmers. Bias toward male farmers is evident in the delivery of extension services which is generally provided by male extension agents to men on the assumption that extension message will órickle acrossê̂ to women. Unfortunately, the evidences clearly show that it often does not (World Bank, 1989). All small- scale farmers, regardless of tribe, race, or gender faced constraints but the focus of this study is on women. It is hoped that the findings of this work will foster better understanding of the gender- related barriers confronting women and also come up with needed recommendations to solve them (Jiriko,1999).

Objective of the study: The broad objective is to examine the extent to which women have access to extension service, credit, and farm inputs in the study area.

The specific objectives are to:

(i) identify the socio-economic characteristics of the women farmers in the study area.

(ii) examine farmersô source and extent of access to credit in the study area.

(iii) examine the womenôs source and extent of access to inputs in the study area.

(iv) assess the frequent and contact of women farmers with extension agents in the study area.

(v) identify constraints to womenô access to inputs, credit and extension agents in the study area.

\section{METHODOLOGY}

The study was conducted in Sabon-Gari Local Government Area of Kaduna State in Northern Nigeria. The Local Government is located in between latitude $11.0^{\circ}$ to $12.0^{\circ}$ North and longitude $7.0^{\circ}$ to $8.0^{\circ}$ East. It has an average altitude of $640 \mathrm{~m}$. There are two distinct seasons: the dry and the wet season. The dry season starts in November and lasts until March while the wet season normally begins in April and ends in October. The mean annual rainfall is $1045 \mathrm{~mm}$ (Samaru Meteorological Service Zaria, 2000). The temperature ranges between $27.0^{\circ}$ to $35^{\circ}$. The area also has dry Sub-humid climate, which is characterized by alternating dry and rainy seasons.

The study area has a population of 606,512 people according to 2006 population census. Sabon-Gari Local Government is divided into two districts namely; Sabon-Gari and Basawa districts. Farming is the major occupation and forms the principal means of livelihood for majority of the populace. Other activities engaged by men and women include trading and hand crafts. The major crops grown in the area include Maize, Millet, Sorghum, Groundnuts, Yam, Cowpea, and Vegetables (Mosimabale, 2010). The area is characterized by small - sized and fragmented land holdings. The Local Government Area is bounded by Giwa Local Government Areas in the West and shares boundaries with Igabi, Makarfi and Zaria Local Government Areas. Agriculture is the largest occupation of the inhabitants (Owolabi, 1994). This research was conducted between June and November 2009.

Sampling technique: Purposive sampling technique was used to select 10 villages from which 60 women farmers were randomly selected. The villages selected were Samaru, Hanwa, Muchia, Shika, and Paladan others are; Basawa, Bomo, Agwan Dan Ayu, Mill Goma. The choice of these ten villages was based on the fact that women in this area are more involved in agricultural practices compared to the women in other area of the Local Government.

Method of Data collection: Primary data were used for this study. The data were collected using interview schedule. The information that was collected includes the socio-economic 
characteristics of women farmers, major factors affecting womenôs access to credit, farm inputs and extension services, and problems confronting farmers in the study area.

Analytical tool: Descriptive statistical tools such as frequency distribution, ranges, and percentages were used to analyze the data for this study.

\section{RESULTS AND DISCUSSION}

Socio-Economic Characteristics

Age distribution: The age distribution of the women can be grouped into three categories. Those less than 20 years as adolescent, 21-40 were classified as youths, 41-60 middle age, and those who fell within the ages 61 and above as old age. Table 1 shows that $63 \%$ of the respondents fell within the youth group, $21 \%$ are middle age $2 \%$ are old age while $13 \%$ are adolescents. The area under study could be classified as economically viable as most (63\%) of the respondents were youth. It could be deduced from this data that the area under study is blessed with human resources. If this potential is properly utilized the area can become one of the richest in the entire State. This finding conforms to that of Abdulkareem (2000) in which age was found to be a factor that can significantly affect the productivity of the farm business. As revealed by this study, women at youth age are expected to be more productive in their farms as majority is still within their prime or active age.

Educational level: The second socio-economic characteristic studied is the educational level which is important for the understanding of improved technologies taken to farmers. The study (Table 2) shows that majority (45\%) of the women have Koranic education, while none $(0 \%)$ were found to have tertiary education. About 18 (30\%) of the respondents had formal education and only two (3\%) were found to have secondary education, $9 \%$ had vocational training, $12 \%$ had primary education, and $7 \%$ had adult education.

The above results evidently indicated that larger percentage $(70 \%)$ of the respondents lack formal education, by implication, it would be difficult for them to obtain loans from financial institutions as this requires formalities such as filling forms. It would also be difficult for them to utilize extension materials as most of this are written in English.

Marital status: The study revealed that majority (67\%) of the respondents were married $13.3 \%$ were widow while $8 \%$ were single and $12 \%$ were divorced (Table 3). The trend in this result showed that the contribution of women farmers in the study area toward agricultural development should be favourable as a reasonable number $(67 \%)$ of them were married and it is expected that they might be able to attract support from their male counterparts.

Table 1: Age distribution.

\begin{tabular}{ccc}
\hline Age & Frequency & Percentage \\
\hline$<20$ & 8 & 13.3 \\
$21-30$ & 23 & 38.3 \\
$31-40$ & 15 & 025 \\
$41-50$ & 10 & 16.7 \\
$51-60$ & 3 & 5.0 \\
$>60$ & 1 & 1.7 \\
Total & $\mathbf{6 0}$ & $\mathbf{1 0 0}$ \\
\hline
\end{tabular}

Table 2: Educational level

\begin{tabular}{lcc}
\hline Level of education & Frequency & Percentage \\
\hline Primary School & 7 & 11.7 \\
Secondary School & 2 & 3.3 \\
Adult education & 4 & 6.7 \\
Koranic School & 27 & 45 \\
Vocational Institution & 5 & 8.3 \\
University & 0 & 0.0 \\
No formal education & 15 & 25 \\
Total & $\mathbf{6 0}$ & $\mathbf{1 0 0}$ \\
\hline
\end{tabular}

Table 3: Marital status

\begin{tabular}{lcc}
\hline Status & Frequency & Percentage \\
\hline Single & 5 & 8.3 \\
Married & 40 & 66.7 \\
Divorced & 7 & 11.7 \\
Widowed & 8 & 13.3 \\
Total & $\mathbf{6 0}$ & $\mathbf{1 0 0}$ \\
\hline
\end{tabular}

It is a common knowledge in traditional peasant agriculture particularly in Nigeria that children are the primary source of family labour. The more children a farmer has the lesser dependence on hired labour and the lesser the cost of production. 
The findings on number of children(Table 4) indicated that eight $(13 \%)$ of the respondents have six and above children, $20 \%$ have four about $48 \%$ have between one and three children, $7 \%$ have no child while $12 \%$ have five children each. The study implies that family labour could be utilized.

Farm size of respondents: Table 5, shows that $39(65 \%)$ of the respondents have between, 0.1 and 1.0 ha hectare of land. Only $25 \%$ have above one hectare a situation, which does not allow for expansion or mechanization. The results also revealed that majority $(90 \%)$ of respondents were small-scale and subsistence farmers, a situation that may not allow them to engage in large production, have access to bigger credit facilities or procure farm inputs. This is because of high capital intensive which agricultural production is known with.

Source of land ownership: Land Ownership system (Table 6) varied among the respondents, $50 \%$ inherited land from their parents or husband $25 \%$ got their farm land through lease and $5 \%$ by gift. Only five respondents $(8 \%)$ were able to buy their farm land. The results imply that the predominant land ownership system is through inheritance. This could also be the reason why they are small scale farmers.

Table 4: Number of children/family

\begin{tabular}{lcc}
\hline No. of children & Frequency & Percentage \\
\hline 0 & 4 & 6.7 \\
1 & 10 & 16.7 \\
2 & 9 & 15 \\
3 & 10 & 16.7 \\
4 & 12 & 20 \\
5 & 7 & 11.7 \\
$>6$ & 8 & 13.3 \\
Total & $\mathbf{6 0}$ & $\mathbf{1 0 0}$ \\
\hline
\end{tabular}

Table 5: Farm size

\begin{tabular}{lcc}
\hline Size of Farm (Ha) & Frequency & Percentage \\
\hline $0.1-1.0$ & 39 & 65.0 \\
$1.1-2.0$ & 15 & 25 \\
$2.1-3.0$ & 3 & 5 \\
$3.1-4.0$ & 2 & 3.3 \\
$4.1-5.0$ & 1 & 1.7 \\
5 and above & 0 & 0.0 \\
Total & $\mathbf{6 0}$ & $\mathbf{1 0 0}$ \\
\hline
\end{tabular}

Table 6: Source of land ownership

\begin{tabular}{llc}
\hline Types of Land Holding & Frequency & $\mathbf{\%}$ \\
\hline In heritance & 30 & 50.0 \\
Purchase & 5 & 8.3 \\
Lease & 15 & 25.0 \\
Rent & 7 & 11.7 \\
Gift & 3 & 5.0 \\
Total & 60 & 100 \\
\hline
\end{tabular}

Farming experience: The data on Table 7 shows that $37 \%$ of the respondents had been farming for between $1-10$ years, $18 \%$ for $31-40$ years and $17 \%$ had $41-50$ years of farming. Also $13 \%$ had 11-20 years farming experience whereas $12 \%$ have been farming for 21-30 years and only 3\% had -50 years and above of farming experience. It could be deduced by this study that all the women interviewed were engaged in agriculture in one form or the other. This indicates active participation of women in agriculture the study area.

Table 7: Farming experience

\begin{tabular}{lcc}
\hline No. of years & Frequency & Percentage \\
\hline$<-10$ & 22 & 36.7 \\
$11-20$ & 8 & 13.3 \\
$21-30$ & 7 & 11.7 \\
$31-40$ & 11 & 18.3 \\
$41-50$ & 10 & 16.7 \\
$>50$ & 2 & 3.3 \\
Total & $\mathbf{6 0}$ & $\mathbf{1 0 0}$ \\
\hline
\end{tabular}

Sources of credit: The second objective of this research is to examine farmersôsource (s) to credit facility, this is because access to credit do increase total output. It can also help Farmer to change his or her desires. Credit can also affect expenditure on the use of mechanical equipment, working capital as well as improved seed. Most of the respondents interviewed though complained of difficulties in securing loan from financial Institutions, about $42 \%$ of them sourced funds from personal saving (adashi) while 28\% made their financial help through cooperatives. $20 \%$ got financial assistance through institutions mostly from Nigeria Agricultural Credit Bank (NACB) probably because of their proximity to the Bank's office in Kwangila-Zaria. It is pertinent that less than $50 \%$ of respondent received financial assistance from informal sources. This could 
hinder their level of production on farm, because the more assistance they get the more they produce.

Income level: The income level refers to the women's legitimate financial income. The third objective of the study is to investigate womenôs level of income. The result shows that out of 60 respondents, $67 \%$ agreed that they have less than N10, 000.00 , whereas only $27 \%$ of the farmers interviewed have above N10, 000.00. The implication of this is that the farmers in the study area may not be opportune to take credit facility. This is because; credit use is associated with higher income than average economic performance. They may not also be able to invest in capital projects like modern farm technology and inputs as this normally attract huge financial obligation considering their low financial status.

Contact with extension agents: The fourth objective of this work is to determine the extent of womenôs contact with extension agents. The data for this study (Table 11) revealed that majority $42 \%$ of farmers had no frequent extension contact. Only $33 \%$ of the respondents had frequent extension contact with extension agents whereas $25 \%$ had no contact at all with extension agents. The implication of this result is that the female farmers lack enough extension contact; this could be due to limited number of extension agents to cover the study area judging from the culture of the Muslim, which prevent female contact with male extension agents. This is a challenge to the agricultural extension specialists when designing the most appropriate strategy for women.

Table 8: Source of credit

\begin{tabular}{lll}
\hline Source & Frequency & Percentage \\
\hline Co-operatives & 14 & 23.3 \\
Personal Saving & 25 & 41.7 \\
Friends/Relatives & 6 & 10.0 \\
Financial Institutions & 12 & 20.0 \\
Money Lenders & 3 & 5.0 \\
Total & $\mathbf{6 0}$ & $\mathbf{1 0 0}$ \\
\hline
\end{tabular}

Table 9: Income level of women farmers per annum

\begin{tabular}{lcc}
\hline Level of income (N) & Frequency & $\mathbf{\%}$ \\
\hline$<10,000.00$ & 40 & 66.7 \\
$11,000-30,000$ & 9 & 15.0 \\
$31,000-60,000$ & 7 & 11.7 \\
$61,000-90,000$ & 4 & 6.7 \\
$91,000-120,000$ & 0 & 0.0 \\
$>20,000$ & 0 & 0.0 \\
Total & $\mathbf{6 0}$ & $\mathbf{1 0 0}$ \\
\hline
\end{tabular}

Constraints faced by women farmers: The farmers in the study area encountered series of problems. Most serious among these problems are land clearing $92 \%$, lack of credit facilities $78 \%$ procurement of farm inputs (modem technology) $95 \%$ and marketing $78 \%$. It was also observed that illiteracy and lack of contact with extension agents were included in the constraints faced by the women.

Table 10: Contact with extension agents

\begin{tabular}{lll}
\hline Responses & Frequency & \% \\
\hline No frequent extension contacts & 25 & 41.7 \\
Had frequent encounter & 20 & 33.3 \\
No extension contacts & 15 & 25.0 \\
Total & 60 & 100 \\
\hline
\end{tabular}

\section{CONCLUSION}

On the bases of the result obtained from this study the following conclusions can be reached, Agriculture is the dominant occupation of the study area, however, majority of the farmer interviewed were still engaged in traditional technology. It was observed that there was a close relationship between the farmersôsampled socioeconomic characteristics and their impact on the agricultural production. Because of farmersôlow level of income it was practically impossible for them to invest in a long term farm enterprise. Such as intensive mechanize farming or a large animal (cattle) production hence they practiced annual cropping system. Most of the farmers in the study area were youth; therefore, they would be able to integrate into a new teaching and to adopt improved technology thereby increasing their productivity. 


\section{RECOMMENDATIONS}

i. The farmers in the study area should be provided with incentives by Government which can motivate them to take challenges. Such as provide credit that needs minimum collateral. Governments, Federal States and Local and all stake holders need to formulate policies that would encourage Banks and credit institutions to extend their network service to women farmers which would facilitate taken of loan and other financial facilities.

ii. More female extension agents should be trained so as to increase the number of extension workers available to women farmers. There is a need to accord women with access to farm inputs such as modern technology in order to reduce drudgery been experienced by female farmers in the study area.

\section{REFERENCE}

Abdulkareem, H. (2000). The role of Rural Women in Agricultural Development: A case study of female farmers in Giwa Local Government Area of Kaduna State. An Unpublished B. Agric. project. Department of Agricultural Economics and Rural Sociology, Ahmadu Bello University, Zaria Nigeria.

Atala, T.K. (1988). Agricultural Extension In Nigeria: Problem And Prospects A Paper Presented At Seminar Organized By Faculty of Agricultural, Ahamadu Bello University, (P.37) Zaria, Nigeria.

Adisa, B. O. And Okunade, E. O. (2005). Women In Agriculture \& Rural Development. Agricultural Extension Society of Nigeria Proceeding, 2005.

Dôsilver, B. and M. Raza. (1980). Integrated rural development in Nigeria: The Funtua project, Food Policy. November Pp.16.
Jiriko, R.K. (1999). Socio-Economic Factors Affecting the Performance of Women In Food Security In Chikun Local Government Area of Kaduna State. An Unpublished Project Proposal, The Department of Agric. Econs. And Rural Sociology. Ahamadu Bello University, Zaria, Nigeria. 1-23.

Mosimabale, V.O. (2010). Analysis of Factors Influencing the Uptake of Improved Seeds Among Rural Farmers in SabonGari Local Government Area of Kaduna State. Msc. Research Proposal, Department of Agricultural Economics And Rural Sociology. Ahamadu Bello University, Zaria, Nigeria. 1-25.

Owolabi J.O. (1994). Adoption of simple farm machineries among small-scale farmers of Sabon-Gari Local Government Area of Kaduna State. An Unpublished Higher Diploma Thesis submitted to School of Agriculture, Ahmadu Bello University, Zaria, Nigeria. Pp. 1-95.

Owolabi, J.O. (2001). Access of Rural Women to agricultural extension agent, input and credit in Sabon-gari Local government area of Kaduna state. An unpublished Postgraduate Diploma (PGD) Project Book. Department of Agricultural Economics and Extension, Usmanu Danfodiyo University, Sokoto, Nigeria. Pp. 1-39.

Saito, K.A. Spurling, D, and Hekonneh, H, (1992). Raising the productivity of women Farmers in sub-Sahara Africa. Discussion paper No. 230 World Bank, Washington D.C.

Samaru Meteorological Service (2000). Meteorological service report, Institute for Agricultural Research, Samaru, Zaria.

World Bank (1989). Kenya: The Role of women in Economic Development. World Bank Country study. Washington, D.C 